\title{
EXAMINING THE RELATIONSHIP BETWEEN SERVICE QUALITY AND CONSUMER REPURCHASE INTENTION WITH MEDIATING ROLE OF GRATITUDE FEELINGS AND MODERATING ROLE OF CORPORATE IMAGE
}

\author{
TEHMINA KANWAL \\ Capital University of Science and Technology, Islamabad, Pakistan
}

\begin{abstract}
The objective of the study was to examine the relationship between service quality (SQ), with mediating role of gratitude feelings (GF), and moderating role of corporate image (CI) on consumer repurchase intention (CRPI). For empirical analysis data was collected from 157 customers of restaurants of Pakistan. The findings disclosed the significant positive relationship between service and consumer repurchase intentions. The results revealed that customers do not follow their gratitude feelings for revisiting any restaurant, and corporate image also do not increase their interest for repeat purchases.
\end{abstract}

\section{INTRODUCTION}

Quality services means delivering companies product and services in such a way that it meets customer's expectations and steering their behavior intention in an accurate way (Zeithaml, Berry, \& Parasuraman, 1996). In service industry quality is one of the most important determinants for retaining consumers (Jr, Brady, \& Hult, 2000). Management puts best efforts to produce quality services to get the competitive advantage over competitors and to form customer's perception about goods and services. Customer perception is the way they evaluate the quality of the services, which directly influences their post purchase behavior (Tam, 2000). Taylor and Baker (1994) found out that when consumers are served with high quality services, they feel turns level of satisfaction and which leads to repurchase intention.

Repurchase behavior is when a customer intends to re-purchase the product in future. Past studies have shown that quality services, values, and customer's satisfaction play a vital role in producing repurchase intentions ( $\mathrm{He} \&$ Song, 2009). To retain customers for long term, companies improve their services by adding value; customers not only enjoy the added value but also prefer to stay with companies (Kuo, Wu, \& Deng, 2009).When companies are wholly responsible for delivering services, and they fail, it directly effects consumers purchase intention negatively. However, if companies provide any valid reasons for their service failure and make sure to improve it in future, it positively effects consumers' decision for future (Grewal, Roggeveen, \& Tsiros, 2008). High service quality increases the customer satisfaction which in return decreases the customer switching behavior, and they want to acquire services again and again (Srivastava \& Sharma, 2013)

Service quality and its relation with consumers purchase intention has been tested in several studies before, but the mechanism though which service quality affects consumer repurchase intention is not well defined; especially the role of gratitude feelings has not been tested (Raggio, Walz, Godbole, \& Folse, 2014).

Gratitude feelings are feelings of appreciation (emotions) for obtained benefits (Folse \& Raggio, 2009). Gratitude is very important for buyer and seller relationships (Raggio et al., 2014). Seller exerts an effort to give his best services to the buyer, which generates gratitude feelings but if the consumer is not relation prone, he/she would consider it an unfair process. (Xia \& Kinney, 2014). Gratitude feelings are produced in an individual when that person gets internally happy (Watkins, Woodward, Stone, \& Kolts, 2003). People show different reactions to services, and their positive and negative feelings are very important elements in either service success or failure (Soscia, 2007). High level of service quality generates positive perceived value which adds in customer satisfaction and positive opinion about the organization (Hu, Kandampully, \& Juwaheer, 2009)

Along with the effort to satisfy customers, another aspect is really important, and that is to retain the customers for longer time period by creating favorable image of the organization in the eyes of the customers (Kandampully \& Suhartanto, 2003). When companies deliver high quality services, and consumers make favorable corporate image in mind, they get satisfied and are more likely to 
repurchase products and less likely to switch the service firm (Srivastava \& Sharma, 2013). Excellent service quality builds a positive image of the corporate, which satisfies customers and attracts people for the product and services (Yu \& Ramanathan, 2012). Customers who are served with high quality services are more likely to form a favorable image (Wu H. C., 2013) which helps in building consumers trust (Lu \& Lin, 2010) so they attach different levels of feelings from the projected corporate image (Lin \& Lu, 2010).

The current study's framework is based on reasoned action plan theory in which consumer's behavioral intention is influenced by his attitude (the way individual perceives quality), and how other people talk about the service provider (corporate image) (Hansen, Jensen, \& Solgaard, 2004). This study intends to explain relationships between quality services, gratitude feelings, corporate image and costumer repurchase intention.

\section{LITERATURE REVIEW}

\section{Quality services and consumers repurchase intention}

In this competitive era, attracting new and retaining existing customers have become a huge challenge for companies (Zhao, Lu, Zhang, \& Chau, 2012). Therefore, to maintain market share, companies have to deliver some kind of value in order to maintain repurchase cycle(Kim, Galliers, Shin, Ryoo, \& Kim, 2012) hence companies are seeking new ways to make their customers more satisfied (Kaura, Durga, \& Sharma, 2015) and happy in order to retain them for a longer period of time.

One way of retaining customers is to improve the quality of products and services which the company is providing. Quality services means the whole impression consumers perceive from the efforts of any organization (Archana \& Subha, 2012). It means companies assess what customers want, and aspire to deliver them accordingly (Olorunniwo, Hsu, \& Udo, 2006) because they believe the way consumers perceive quality of services it has a direct impact on their future intention (Lee, Kim, Ko, \& Sagas, 2011). This is why, service organizations design different strategies to satisfy customers as organizations know that the satisfied consumers will plan to stay with service providers and spread positive words about it or, if not, they would prefer to switch to other service providers (Athanassopoulos, Gounaris, \& Stathakopoulos, 2001).

There are so many aspects of improving service quality, but the tangible aspect of quality services is very important to convince customers to buy products (Al Khattab \& Aldehayyat, 2011).Tangible means facilities, i.e., comfortable environment, refreshment and service provider treatment (Han, Ham, Yang, \& Baek, 2012) along with other features. In hotel industry three dimensions of quality services are reliability, assurance and empathy which are positively associated with customers' behavioral intention (Ahamed \& Mohideen, 2015). Similarly, for online shopping, the website quality is an important key for customer satisfaction and purchase behavior (Shin, Chung, Oh, \& Lee, 2013) which suggest that high levels of services positively motivate consumers for future purchases (Kuo \& Tang, 2013).

\section{Hypothesis 1. Quality services have a significant positive impact on consumer repurchases intention.}

\section{Gratitude feelings as a mediator between service quality and consumer repurchase intention}

Gratitude feelings are intrinsic emotions (Algoe, Fredrickson, \& Gable, 2013) which means positive and negative emotions that describe consumers feelings about any product and services (Laros \& Steenkamp, 2005). Gratitude is a mechanism for building relationships (Algoe, Gable, \& Maisel, 2010). When consumers purchase anything it either generates pride or guilt for the transaction (Antonetti \& Maklan, 2014). If companies meet customers' expectations, it generates a sense of appreciation, that satisfies customers and ultimately lead to higher sales from the repurchase cycle (Yee, Yeung, \& Cheng, 2011); but if companies fail in delivering what customers want, they are more likely to switch to some other source(Malik, Ghafoor, \& Iqbal, 2012).

Consumers buying decision is effected by different factors such as the information which buyers get from different people, service quality provided by service provider, and his own feelings and personality (Arslan \& Zaman, 2014). Emotions effect consumer's behavior differently in different situations, especially cognitive approach helps in building consumption behavior (Watson \& Spence, 2007). Similarly, Gratitude feelings have a considerable impact on individual's satisfaction (Lavy \& Ovadia, 2011), which means, people with high gratitude feelings are more happy and fulfilled as compare to people with less gratitude feelings (Chan, 2010). In other words, grateful people are more likely to make purchases again and again from the company, and they tend to spread positive words. Customers trust companies for what they offer (Poolthong \& Mandhachitara, 2009) and value their efforts. Hence, Companies struggle hard to meet the customer's expectations and to generate their positive behavior about the company. Since customer's favorable behavior means willingness to purchase products again and to spread positive words for obtained product and services(Lai \& Chen, 2011), that is why companies provide excellent services to their customers 
to ensure their future revisits (Dlacic, Arslanagic, Maglajlic, Markovic, \& Raspor, 2013).

In restaurants settings consumers express their gratitude to service provider by giving tips. It could be a significant tip or a small tip. The amount of tip depends on service provided (Lynn \& McCall, 2000). Different companies design different marketing strategies such as delivering gifts (free lunch, tickets, special sales offer) to their existing and potential customers to generate gratitude feelings, and consumers express their gratitude in the form of purchasing from companies in future as well (Bodur \& Grohmann, 2005). A result of a study in a wine industry indicated that people who receive special attention and warmth at wineries, they develop some unobvious emotions such as gratitude feelings, which significantly affect consumers to reciprocate their feelings by purchasing wine (Kolyesnikova \& Dodd, 2009; N., H., \& A, 2006)

\section{Hypothesis 2. Gratitude feelings mediate the relationship between service quality and customers repurchase intention.}

\section{Corporate image as a moderator between service quality and consumer repurchase intention}

Corporate image is very important to remain in the market and to capture the maximum market share. It also describes how much customers can rely on a company. Buyer's information about any brand or product influences his decision for purchase (Wang \& Yang, 2010). Customers get attracted towards brand which is providing two benefits; one is good appearance and the other is functionality of the brand (Sondoh Jr., Omar, Wahid, Ismail, \& Harun, 2007). Appearance of a brand such as logo design, color, style, facilities and physical environment all this association helps in developing brand image (Alexandris, Douka, Papadopoulos, \& Kaltsatou, 2008).

Companies take a lot of steps to build corporate image (Javalgi, Traylor, Gross, \& Lampman, 1994) because it not only makes consumers perception but also affect their buying attitude (Wu, Liao, \& Tsai, 2012). However, a brand with great look and feel projects a well established corporate image (Martenson, 2007) and stays in consumers mind. Consumers give high preferences to the well recognized brands (Chi, Yeh, \& Yang, 2009) because of the trust for products quality (Chiang \& Jang 2007) and the experiences they already had with them.

Corporate brand image influences consumers mind for company's product and services (Berens, Riel, \& Bruggen, 2005); it also determines customer's loyalty in terms of staying with the company for a long time period
(Cretu \& Brodie, 2007). In case of a good experience, image of the company gets stronger in the eyes of consumers and vice versa. This is why good quality services have a direct impact on corporate image, (Lai, Griffin, \& Babin, 2009). Similarly, to increase customers' revisits, companies need not only to focus on customers' satisfaction, but also on creating the favorable image (Ryu, Han, \& Kim, 2008). Shukla's (2011) study on luxury products showed that brand image influences customer purchase behavior because consumers want to establish a superior image in front of others. Wu C. C. (2011) study on hospitals showed that positive hospital image not only satisfy patients but also force them to revisit. High quality services provided by the positively established name resists customer from switching brand (Nguyen \& LeBlanc, 1998)

Hypothesis 3. Corporate image moderates the relationship in such a manner that it strengthens the relationship between service quality and consumers purchase intention.

\section{FRAMEWORK}

FIGURE 1

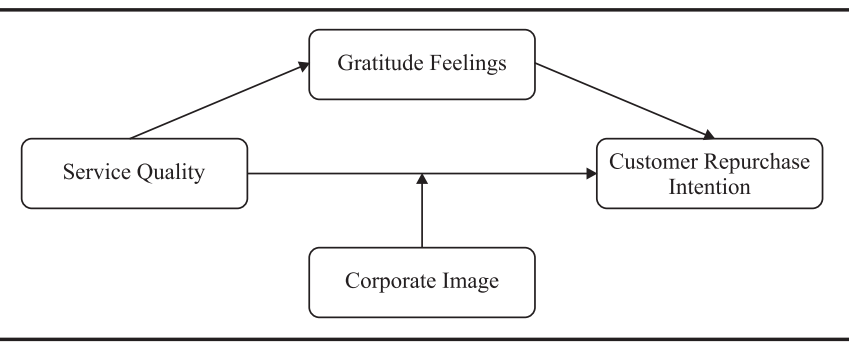

\section{RESEARCH METHODOLOGY}

This was a co relational study and the primary data was collected through a tested and validated questionnaire. Data for "service quality" was collected using an instrument adapted from Pamies (2012). Responses for "gratitude feelings" and "customer purchase intention" were collected using an instrument adapted from Palmatier, Jarvis, Bechkoff, and Kardes (2009). "Corporate image" data were collected using an instrument adapted from Chen \& Chen (2014). Unit of analysis was the customers of restaurants of Rawalpindi and Islamabad. The questionnaire was based on five points likert scale with 1 "strongly disagrees" to 5 "strongly agree". There were 21 questions for the "service quality" with Cronbach Alpha of ".919". Three questions for "Gratitude feelings" and 10 questions for "corporate image" were incorporated with Cronbach Alpha of ".775" and ".899" respectively. There were only 3 items for "consumer repurchase intention" with cronbach Alpha of ".667".

Questionnaires were distributed among customers 
of different restaurants through convenient and snowball sampling technique. The purpose of this research was explained at the top of the survey sheet and the participation of customers in the survey was totally subjected to customer's convenience. A total of 300 questioners were floated, of which 150 were shared online to different visitors of restaurants (57 responses), the rest of 150 were floated off-line at various places to students, employees and self employed people (100 responses). Overall 157 responses were received.

\section{TABLE 1}

Demographics

\begin{tabular}{lccc}
\hline Demographics & Range & Frequencies & Percentage \\
\hline Gender & Male & 94 & 59.9 \\
Age & Female & 63 & 40.1 \\
& $20-30$ & 103 & 65.6 \\
& $31-40$ & 37 & 23.6 \\
Education & $41-50$ & 15 & 9.6 \\
& 50 above & 2 & 1.3 \\
& Below & 35 & 22.3 \\
& Bachelors & & \\
& Bachelors & 74 & 47.1 \\
Income & Masters & 43 & 27.4 \\
& PhD & 5 & 3.2 \\
& $15000-25000$ & 66 & 42.0 \\
& $26000-35000$ & 36 & 22.9 \\
& $36000-45000$ & 26 & 16.6 \\
& More than & 29 & 18.5 \\
\hline & 45000 & & \\
\hline
\end{tabular}

$N=157$

The demographic table shows that $59.9 \%$ respondents were male and $40.1 \%$ respondents were female. The maximum respondents were between 20 30 years whom were $65.6 \%$ and rests of all were above 30 years. Bachelor's degree holders were $47.1 \%, 27.4 \%$ Master degrees and 3.2\% were having $\mathrm{PhD}$ degrees. The majority of respondents $(42 \%)$ were from income level of PKR 15,000-25,000 while $18.5 \%$ belonged to income level more than PKR 45,000.

\section{RESULTS}

Table 2 represents means, standard deviation and correlations among variables. Correlation table shows that all the variables were significantly correlated that ranges from 0.523 to 0.81 with no multicollinearity issues. All correlation values are significant at $\mathrm{P}<0.01$. Service quality is significantly associated with Gratitude feelings $\left(\mathrm{p}<0.01, \mathrm{r}=0.758^{* *}\right)$ which shows that if quality services are provided to customers, they are more likely to be grateful to the restaurant.

TABLE 2

\begin{tabular}{llllllll}
\hline & Variables & Means & S.D & 1 & 2 & 3 & 4 \\
\hline 1 & $\begin{array}{l}\text { Service } \\
\text { quality }\end{array}$ & 3.71 & .641 & 1 & & & \\
2 & $\begin{array}{l}\text { Gratitude } \\
\text { feelings }\end{array}$ & 3.67 & .861 & $.758^{* *}$ & 1 & & \\
3 & $\begin{array}{l}\text { Corporate } \\
\text { image }\end{array}$ & 3.71 & .767 & $.817^{* *}$ & $.734^{* *}$ & 1 & \\
4 & $\begin{array}{l}\text { Consumer } \\
\text { repurchase } \\
\text { intention }\end{array}$ & 3.71 & .840 & $.589^{* *}$ & $.523^{* *}$ & $.705^{* *}$ & 1 \\
\hline$* *$ & $\begin{array}{l}\text { Correlation } \\
\text { Cis }\end{array}$ & significant & at & $p<0.01$ & level \\
(2-tailed) & & & & & & &
\end{tabular}

Corporate image and service quality is strongly linked with each other $\left(\mathrm{P}<0.01, \mathrm{r}=0.817^{* *}\right)$ which is a clear indication that quality services influence restaurant image in the eyes of customers.

There is also a significant correlation between quality services and consumers repurchase intention $\left(\mathrm{P}<0.01, \mathrm{r}=0.589^{* *}\right)$. This means that a high quality service compels consumers to revisit the restaurants in future. Similarly Gratitude feelings have a strong relationship with corporate image and consumers repurchase intention $\left(\mathrm{p}<0.01, \mathrm{r}=0.734^{* *}\right.$ and $\mathrm{r}=$ $0.523^{* *}$ ) respectively.

\section{Regression Analysis}

For the purpose of regression analysis, Barron and Kenny method was used. A step wise analysis was performed to test the predictions. We entered gender, age, education and income as control variables.

\section{Service quality and consumer repurchase intention}

For hypothesis $\mathrm{H}_{1}$, we tested the regression analysis of service quality with consumer repurchase intention. Result has shown a significant relation between both Variables with $(\beta=.767)$ and $\left(\mathrm{R}^{2}=.351\right)$ at significance level $(\mathrm{p}<.000)$. Hence, hypothesis $\mathrm{H}_{1}$ is accepted.

\section{Gratitude Feelings}

The hypothesis about Gratitude feelings predicted that, it mediates the relationship between service quality and consumer repurchase intention. To test this hypothesis, we performed regression analysis of variable service quality and Gratitude feelings with consumer repurchase intention. To run this test, we first entered control variables. In next step we controlled gratitude feelings and in last step we entered independent variable. 
TABLE 3

Mediation Analysis

\begin{tabular}{lccc}
\hline Predictors & $\boldsymbol{\beta}$ & $\mathbf{R}^{\mathbf{2}}$ & $\Delta \mathbf{R}^{\mathbf{2}}$ \\
\hline Step 1 & & & \\
Control variables & & .012 & \\
Step 2 & & & \\
Gratitude feelings & .511 & .277 & .265 \\
Step 3 & & \\
Quality services & & .363 & .086 \\
Significance level $p<=.000, N=157$
\end{tabular}

The results showed that a gratitude feelings partially mediates the relationship between the service quality and consumer repurchase intention with $\left(\mathrm{R}^{2}=.363\right)$ at significance level $(\mathrm{p}<.000)$ and which disconfirms the $\mathrm{H}_{2}$.

\section{Corporate image}

Hypothesis $\mathrm{H}_{3}$ was, corporate image moderates the relationship between service quality and consumers repurchase intention in such a manner that it strengthens the relationship. To test this prediction, regression analysis of independent variable "service quality" was carried out with moderating variable "corporate image". All control variables were used in first step. In next step, we entered service quality and corporate image to see its impact on consumer repurchase intention. Then, in third step, interaction term was used.

\section{TABLE 4}

\section{Moderation Analysis}

\begin{tabular}{lccc}
\hline Predictors & $\boldsymbol{\beta}$ & $\mathbf{R}^{2}$ & $\Delta \mathbf{R}^{2}$ \\
\hline Step 1 & & & \\
Control variables & & .012 & \\
Step 2 & & & \\
Service quality & .040 & .500 & .488 \\
Corporate image & .748 & & \\
Step 3 & & & \\
Service quality x corporate image & -.031 & .501 & .001 \\
\hline
\end{tabular}

Significance level $p=0.682$

The interaction term result was insignificant as change in $\mathrm{R}$ is .001 at $\mathrm{P}$ is 0.682 , which is higher than significance level $\mathrm{p}<0.05$. The result of regression analysis also disconfirms this relationship of variables.

\section{DISCUSSION}

In a competitive era where consumers have multiple options to meet a single need, retaining customers for a long time has become a real time challenge. In this study, relationship between quality services, gratitude feelings, corporate image and consumer repurchase intentions have been tested in Pakistani restaurants context. Three hypotheses were developed; based on extensive literature review. The results have shown that, provision of quality services is an eventual solution for companies for their survival.

The current study initially tested the first hypothesis; quality services show a significant relationship with consumers repurchases intention. The results are aligned with previous studies, and it has been learnt that if quality services such as facilities, comfortable environment and other recreational activities are provided to consumers they will repurchase it in future (Wu, Liao, \& Tsai, 2012). Similarly another study revealed that mangers gauge consumers' needs and wants, and they try to deliver them accordingly and attract consumers for a longer time period (Olorunniwo et al., 2006).

Contrary to previous studies, i.e., gratitude feelings have a positive impact on consumers repurchase intention; there are many possible reasons for disconfirmation of the prediction. Firstly, respondents might have not experienced any extra effort in Pakistani restaurants scenario and they might be comparing it with some internationally recognized brands which led their expectations high. Other possibility could be that, in Pakistan, public is least educated about their rights. In particular, people have no or very little understanding of consumers rights. If they are being misguided and cheated or sometimes consumers are being overly compensated with benefits, they are unable to differentiate that they are being treated differently, and they don't develop sense of recognition and appreciation. The other possibility could be respondent's biasness. Pakistan is an under developed country, and the research culture is developing slowly; people at times don't show interest in the research activities and do not mark their true perceptions on the instrument. Hence there is also a possibility of biasness from the respondent.

The final hypothesis about corporate image was also rejected. The World Bank's Poverty Head Count Analysis 2014 revealed that poverty line is two dollar per day and according to this standard $60.19 \%$ people are living under poverty line. This means people are unable to earn PKR 200 per day for their food and other basic needs. A very less percentage of people fall under middle class and almost $62 \%$ percent people are living in rural areas, and living simple lives. So, people have other worries to earn bread for their living than getting fascinated by projected corporate image. Along with this, a huge number of people are living in backward areas where there is no concept of dinning out because of restricted culture. Even the establish corporate image of restaurants do not work for urban areas because people prefer family gatherings over 
restaurants because of collectivist culture and religious environment.

\section{IMPLICATION}

The study has practical implication for restaurants managers. Managers should design training programs for employees. They should train their employees in such a manner, where they can serve the customers effectively. Training should include how to deal customers, and how effectively they can deliver their service on time to generate gratitude feelings in customers. Along with this, interior look and extra services like internet or recreational facilities should be given to consumers to make them permanent customers.

Customers reward to companies which are putting special effort for them. Mangers should design schemes such as wishing birthdays to its customers or share some presents and birthday card to make them feel special. May be a restaurant sends a free dinner voucher to its customers on wedding anniversary to make them feel how much they care about their customers' special events. This whole effort could lead to customer's happiness and ultimately benefit the business in long term.

\section{LIMITATIONS AND FUTURE RESEARCH}

The present study has some limitation and acknowledgement of these limitations gives new direction for research. First, we have used a convenience sampling technique for gathering data of customers of Rawalpindi and Islamabad. To obtain more detailed understanding, future researches must expand the geographic limitation to the whole country. Secondly, data was collected only once, to see a more accurate result it can be gathered in different time lags. If respondents are educated, the importance of this research work and given benefits for sharing their true perceptions would result in a bias free study. Finally, this study is limited to Pakistani restaurants contexts; this conceptual model can be replicated in other industries to test the relationship.

\section{CONCLUSION}

Developing economies are highly dependent on small businesses, and restaurant industry is one among them. Restaurants have gone beyond the scope of nationalities and are being operated globally. This tense competitive environment makes survival extremely difficult. Marketers are striving to create and retain their customers. They are using numerous means to create an image in the minds of customers and to remain in the top choices. Pakistani restaurants are also facing difficulties in creating a good corporate image in the minds of its customers. They have succeeded in establishing customer repurchase intention through delivering quality services, also it was identified that gratitude feelings were lesser quantum contributors to service quality and repurchase intentions.

\section{REFERENCES}

Ahamed, D. L., \& Mohideen, D. R. (2015). Service quality and guests behavioural intentions: A study in the kodaikanal star hotels.. International Journal of Management, 459-467.

Al Khattab, S. A., \& Aldehayyat, J. S. (2011). Perceptions of Service Quality in Jordanian

Hotels. International Journal of Business and Management, 226-233.

Alexandris, K., Douka, S., Papadopoulos, P., \& Kaltsatou, A. (2008). Testing the role of service quality on the development of brand associations and brand loyalty. Managing Service Quality, 239-254.

Algoe, S. B., Fredrickson, B. L., \& Gable, S. L. (2013). The Social Functions of the Emotion of Gratitude via Expression. American Psychological Association, 605-609.

Algoe, Sara B.; Gable, Shelly L.; Maisel, Natalya C. (2010). It's the little things: Everyday gratitude as a booster shot for romantic relationships. Personal Relationships, 217-233.

Antonetti, P., \& Maklan, S. (2014). Feelings that Make a Difference: How Guilt and Pride Convince Consumers of the Effectiveness of Sustainable Consumption Choices. J Bus Ethics , 117-134.

Archana, R., \& Subha, D. V. (2012). A study on service quality and passenger satisfaction on indian airlines. International Journal of Multidisciplinary Research, 50-63.

Arslan, M., \& Zaman, R. (2014). Impact of Brand Image and Service Quality on Consumer Purchase Intention: A Study of Retail Store in Pakistan. Research on Humanities and Social Sciences , 98105.

Athanassopoulos, A., Gounaris, S., \& Stathakopoulos, V. (2001). Behavioural responses to customer satisfaction: an empirical study. European Journal of Marketing, 687-707.

Berens, G., Riel, C. B., \& Bruggen, G. H. (2005). Corporate Associations and Consumer Product Responses: The Moderating Role of Corporate Brand Dominance. Journal of Marketing, 35-48.

Bodur, H. O., \& Grohmann, B. (2005). Consumer Responses to Gift Receipt in Business-to-Consumer Contexts. Psychology \& Marketing, 441-456.

Chan, D. W. (2010). Gratitude, gratitude intervention and subjective well-being among Chinese school 
teachers in Hong Kong. Educational Psychology, 139-153.

Chen, W. J., \& Chen, M. L. (2014). Factors Affecting the Hotel's Service Quality: Relationship Marketing and Corporate Image. Journal of Hospitality Marketing \& Management, 77-96.

Chi, D. H., Yeh, D. H., \& Yang, Y. T. (2009). The Impact of Brand Awareness on Consumer Purchase Intention:The Mediating Effect of Perceived Quality and Brand Loyalty. The Journal of International Management Studies, 135-144.

Chiang PhD, C. F., \& Jang PhD, S. S. (2007). The Effects of Perceived Price and Brand Image on Value and Purchase Intention: Leisure Travelers' Attitudes Toward Online Hotel Booking . Journal of Hospitality \& Leisure Marketing, 49-69.

Cretu, A. E., \& Brodie, R. J. (2007). The influence of brand image and company reputation where manufacturers market to small firms: A customer value perspective. Industrial Marketing Management, 230 - 240.

Dlacic, J., Arslanagic, M., Maglajlic, S. K., Markovic, S., $\&$ Raspor, S. (2013). Exploring perceived service quality, perceived value, and repurchase intention in higher education using structural equation modelling. Total Quality Management \& Business Excellence, 141-157.

Folse, J. A., \& Raggio, R. D. (2009). Gratitude works: its impact and the mediating role of affective commitment in driving positive outcomes. $J$. of the Acad. Mark. Sci, 455-469.

Grewal, D., Roggeveen, A. L., \& Tsiros, M. (2008). The Effect of Compensation on Repurchase Intentions in Service Recovery. Journal of Retailing, 424434.

Han, S., Ham, S. (., Yang, I., \& Baek, S. (2012). Passengers' perceptions of airline lounges: Importance of attributes that determine usage and service quality measurement. Tourism Management, 1103-1111.

Hansen, T., Jensen, J. M., \& Solgaard, H. s. (2004). Predicting online grocery buying intention: a comparison of the theory of reasoned action and the theory of planned behavior. International Journal of Information Management, 539-550.

He, Y., \& Song, H. (2009). A Mediation Model of Tourists' Repurchase Intentions for Packaged Tour Services. Journal of Travel Research, 317-331.

Hu, H. H., Kandampully, J., \& Juwaheer, T. D. (2009). Relationships and impacts of service quality, perceived value, customer satisfaction, and image: an empirical study. The Service Industries Journal, 111-125.

Javalgi, R. G., Traylor, M. B., Gross, A. C., \& Lampman,
E. (1994). Awareness of Sponsorship and Corporate Image:An Empirical Investigation. Journal of Advertising, 47-58.

Jr, J. J., Brady, M. K., \& Hult, G. T. (2000). Assessing the Effects of Quality, Value, and Customer Satisfaction on Consumer Behavioral Intentions in Service Environments. Journal of Retailing, 193218.

Kandampully, J., \& Suhartanto, D. (2003). The Role of Customer Satisfaction and Image in Gaining Customer Loyalty in the Hotel Industry. Journal of Hospitality \& Leisure Marketing, 3-25.

Kaura, V., Durga, C. S., \& Sharma, P. S. (2015). "Service quality, service convenience, price and fairness,customer loyalty, and the mediating role of customer satisfaction",. International Journal of Bank Marketing, 1-27.

Kim, C., Galliers, R. D., Shin, N., Ryoo, J. H., \& Kim, J. (2012). Factors influencing Internet shopping value and customer repurchase intention. Electronic Commerce Research and Applications, 374-387.

Kolyesnikova, N., \& Dodd, T. H. (2009). There is no such thing as a free wine tasting:the effect of a tasting fee on obligation to buy. Journal of Travel \& Tourism Marketing, 806-819.

Kuo, C. W., \& Tang, M. L. (2013). Relationships among service quality, corporate image, customer satisfaction, and behavioral intention for the elderly in high speed rail services. Journal Of Advanced Transportation, 512-525.

Kuo, Y. F., Wu, C. M., \& Deng, W. J. (2009). The relationships among service quality, perceived value, customer satisfaction, and post-purchase intention in mobile value-added services. Computers in Human Behavior, 887-896.

Lai, F., Griffin, M., \& Babin, B. J. (2009). How quality, value, image, and satisfaction create loyalty at a Chinese telecom. Journal of Business Research, 980-986.

Lai, W. T., \& Chen, C. F. (2011). Behavioral inten tionsofpublictransitpassengers-The roles of service quality, perceivedvalue,satisfaction and involvement. Transport Policy, 318-325.

Laros, F. J., \& Steenkamp, J.-B. E. (2005). Emotions in consumer behavior: a hierarchical approach. Journal of Business Research, 1437- 1445.

Lavy, S., \& Ovadia, H. L. (2011). All you need is love? Strengths mediate the negative associations between attachment orientations and life satisfaction. Personality and Individual Differences, 1050 1055.

Lee, J. H., Kim, H. D., Ko, Y. J., \& Sagas, M. (2011). The influence of service quality on satisfaction and intention: A gender segmentation strategy. Sport 
Management Review, 54-63.

Lin, L. -Y., \& Lu, C. Y. (2010). The influence of corporate image,relationship marketing, and trust on purchase intention: the moderating effects of word-of-mouth . Tourism Review, 16 - 34.

Lu, C. Y., \& Lin, L. Y. (2010). The influence of corporate image, relationship marketing, and trust on purchase intention: the moderating effects of word-of-mouth. Tourism Review, 16 - 34.

Lynn, M., \& McCall, M. (2000). Gratitude and gratuity: a meta-analysis of research on the service-tipping relationship. Journal of Socio-Economics, 203214.

Malik, P. D., Ghafoor, M. M., \& Iqbal, H. K. (2012). Impact of Brand Image, Service Quality and price on customer satisfaction in Pakistan Telecommunication sector. International Journal of Business and Social Science, 123-129.

Martenson, R.(2007). Corporatebrand image,satisfaction and store loyalty A study of the store as a brand, store brands and manufacturer brands. International Journal of Retail \& Distribution Management, 544-555.

N., K., H., D. T., \& A., L. D. (2006). Importance of winery visitor group size on feelings of gratitude and obligation. 3rd International Wine Business Research Conference, Montpellier, (pp. 1-20).

Nguyen, N., \& LeBlanc, G. (1998). The mediating role of corporate image on customers' retention decisions: an investigation in financial services. International Journal of Bank Marketing, 52-65.

Olorunniwo, F., Hsu, M. K., \& Udo, G. J. (2006). Service quality, customer satisfaction, and behavioral intentions in the service factory. Journal of Services Marketing, 59-72.

Palmatier, R. W., Jarvis, C. B., Bechkoff, J. R., \& Kardes, F. R. (2009). The Role of Customer Gratitude in Relationship Marketing. Journal of Marketing, $1-18$.

Pamies, D. S. (2012). Customer loyalty to service providers:examining the role of service quality,customer satisfaction and trust. Total Quality Management \& Business Excellence, 1257-1271.

Poolthong, Y., \& Mandhachitara, R. (2009). Customer expectations of CSR,perceived service quality and brand effect in Thai retail banking. International Journal of Bank Marketing, 408-427.

Raggio, R. D., Walz, A. M., Godbole, M. B., \& Folse, J. A. (2014). "Gratitude in relationship marketing". European Journal of Marketing, 2 - 24.

Ryu, K., Han, H., \& Kim, T. H. (2008). The relationships among overall quick-casual restaurant image,perceived value, customer satisfaction, and behavioral intentions. International Journal of
Hospitality Management, 459-469.

Shin, J. I., Chung, K. H., Oh, J. S., \& Lee, C. W. (2013). The effect of site quality on repurchase intention in Internet shopping through mediating variables: The case of university students in South Korea. International Journal of Information Management, 453-463.

Shukla, P. (2011). Impact of interpersonal influences, brand origin and brand image on luxury purchase intentions: Measuring interfunctional interactions and a cross-national comparison. Journal of World Business, 242-252.

Sondoh Jr., S. L., Omar, M. W., Wahid, N. A., Ismail, I., \& Harun, A. (2007). The effect of brand image on overall satisfaction and loyality intentions in the context of colour cosmetics. Asian Academy of Management Journal, 83-107.

Soscia, I. (2007). Gratitude, Delight, or Guilt:The Role of Consumers' Emotions in Predicting Postconsumption Behaviors. Psychology \& Marketing, 871-894.

Srivastava, K., \& Sharma, N. K. (2013). Service Quality, Corporate Brand Image, and Switching Behavior: The Mediating Role of Customer Satisfaction and Repurchase Intention. Services Marketing Quarterly, 274-291.

Tam,J.L.(2000). TheEffects ofServiceQuality,Perceived Value and Customer Satisfaction on Behavioral Intentions. Journal of Hospitality \& Leisure Marketing, 31-43.

Taylor, S. A., \& Baker, T. L. (1994). An Assessment of the Relationship Between Service Quality and Customer Satisfaction in the Formation of Consumers' Purchase Intentions. Journal of Retailing, 163-178.

Wang, X., \& Yang, Z. (2010). The Effect of Brand Credibility on Consumers'Brand Purchase Intention in Emerging Economies: The Moderating Role of Brand Awareness and Brand Image. Journal of Global Marketing, 177-188.

Watkins, P. C., Woodward, k., Stone, T., \& Kolts, R. L. (2003). Gratitude and happiness:Development of a measure of Gratitude,And Relationship With Subjective Well-being. Social Behavior and Personality, 431-452.

Watson, L., \& Spence, M. T. (2007). Causes and consequences of emotions on consumer behaviour A review and integrative cognitive appraisal theory. European Journal of Marketing, 487-511.

$\mathrm{Wu}$, C. C. (2011). The impact of hospital brand image on service quality, patient satisfaction and loyalty. African Journal of Business Management, 4873-4882.

Wu, H. C. (2013). An Empirical Study of the Effects of Service Quality, Perceived Value, Corporate Image, 
and Customer Satisfaction on Behavioral Intentions in the Taiwan Quick Service Restaurant Industry . Journal of Quality Assurance in Hospitality \& Tourism, 364-390.

Wu, H. C., Liao, L. C., \& Tsai, T. F. (2012). A Study of Relationships among Consumer Cognition of Spa Hotel Brand, Service Quality,Experience, and Repurchase Intention. International Conference on Innovation, Management and Technology Research, 21-22.

Wu, H. C., Liao, L. C., \& Tsai, T. F. (2012). A Study of Relationships among Consumer Cognition of Spa Hotel Brand, Service Quality,Experience, and Repurchase Intention. International Conference on Innovation, Management and Technology Research, (pp. 148-151). Malacca.

Xia, L., \& Kinney, M. K. (2014). For our valued customers only: Examining consumer responses to preferential treatment practices. Journal of
Business Research, 2368-2375.

Yee, R. W., Yeung, A. C., \& Cheng, T. (2011). The service-profit chain:An empirica lanalysis in high-contact service industries. Int. J. Production Economics, 236-245.

Yu, W., \& Ramanathan, R. (2012). Retail service quality, corporate image and behavioural intentions:the mediating effects of customer satisfaction. The International Review of Retail, Distribution and Consumer Research, 485-505.

Zeithaml, V. A., Berry, L. L., \& Parasuraman, A. (1996). The Behavioral Consequences of Service Quality. Journal of Marketing, 31-46.

Zhao, L., Lu, Y., Zhang, L., \& Chau, P. Y. (2012). Assessing the effects of service quality and justice on customer satisfaction and the continuance intention of mobile value-added services: An empirical test of a multidimensional model. Decision Support Systems, 645-656. 